DOI: https://doi.org/10.18485/philologia.2020.18.18.4 UDC: 821.111(73)-31.09 Tan A.

\title{
MOTHERS AND DAUGHTERS IN AMY TAN'S THE KITCHEN GOD'S WIFE AND THE JOY LUCK CLUB
}

\author{
MARIA CRISTINA CHINTESCU ${ }^{1}$ \\ University of Craiova \\ Craiova, Romania
}

Centralna tema rada je fenomen „Drugosti” u romanima Ejmi Tan Žena boga kuhinje i Klub radosti i sreće. Autor rada osvrće se na sve osobenosti ovog fenomena, ukazujući na četiri moguće: kinesko-američki ženski identitet u priči o Perl, pripadnost i nepripadnost grupi, položaj žena unutar društva i heterogenost prostora. „Drugost” se u radu tako analizira kroz odnos ćerke, rođene u Americi, Perl Luj Brent, i majke, Vini Luj, poreklom iz Kine. Takođe se ističe i različitost između onih koji pripadaju krugu grupe (Indijanaca) i onih van nje (Kineza). Najzad, u radu se raspravlja i o heterogenosti prostora u jednom društvu, što je od ključne važnosti za temu „Drugosti”.

Ključne reči: Žena boga kuhinje, Klub radosti i sreće, Kineskinje, tradicija, identitet, rasa, stereotipi, borba.

\section{INTRODUCTION}

Starting from the initial hypothesis that Otherness in Amy Tan's novels The Kitchen God's Wife and The Joy Luck Club has four specific peculiarities (the Sino-American female identity, the In-group and the Out-group concept, the place of women within a patriarchal society, and the special heterogeneity of society), the author intends to do the following in this paper:

- Identify and describe the main points when talking about assimilation and ethnicity in the Chinese Diaspora (in The Kitchen God's Wife and The Joy Luck Club);

- Introduce the subjects of family, history and culture (The Kitchen God's Wife and The Joy Luck (lub);

- Emphasize the Iconic Figure of the Mother as one of the Greatest Moms (The Kitchen God's Wife and The Joy Luck Club);

1 Kontakt podaci (Email): ina_maria2004@yahoo.com 
- Identify and discuss The Alterity between the Chinese and American Worlds (The Kitchen God's Wife and The Joy Luck Club);

- Identify and bring to discussion the subject of Stereotypes and Faith within the Chinese ethnic organizations (The Kitchen God's Wife and The Joy Luck Club).

When talking about Chinese America, it should be clarified that it is part of the Greater Chinese Diaspora. The international migration among Chinese is centuries old: long before European colonists invaded the Asian continent, the Chinese moved by sea or land, either seasonally or permanently, with the aim to earn a living and support their families. Amy Tan offers a historical view of Chinese emigration as a basis for understanding Chinese immigration to the United States. Diaspora is reflected in an old saying: "There are Chinese people wherever the ocean waves touch."

Chinese Americans concentrate mostly in urban areas: over half of them live in metropolitan regions: New York, Los Angeles, and San Francisco. Amy Tan's characters' settlements are in San Francisco as it serves as a gateway and a new urban center of Asian settlement across the country.

\section{ASSIMILATION AND ETHNICITY}

When talking about Chinese immigration, we are first stricken by the fact that the community is largely dominated by first-generation immigrants. The female characters in The Joy Luck Club, The Kitchen God's Wife or The Hundred Secret Senses come to prove this phenomenon. They have brought their ethnic organizations and ethnic social networks to America and they remain undisputed no matter what. Eventually, when these familiar networks are missing, they make them out by finding persons who will become "sisters, aunts, uncles, cousins" despite not being related to these persons. For instance, after a lifetime, Pearl, one of the main characters in The Kitchen God's Wife, finds out that her mother made up for her an aunt, Helen, and two cousins with whom she has no blood connections. Moreover, she finds out that her real father is not Jimmy Louie who brought her up, but a dreadful and abusive Chinese man, her mother's first husband about whom nobody has ever talked before. The characters are described with pervasive discrimination, lack of English language proficiency or information about the new homeland.

\section{FAMILY, HISTORY AND CULTURE}

The members of this Chinese community were expected to assimilate in the American traditions and the American way of living, as most immigrants have done, but they have not. They do not do this assimilation process in the way Africans or Mexicans do. They persistently continue to keep their identity, they keep their traditions and superstitions alive. America is an open pot but the Chinese world has remained untouched by American temptations. They follow their own rules which are not to be broken or offended. They deny their country but at the same time they love it so much. 
It is valued, uncontested, and always in their heart. On the other hand, members of the second or later generations are unlikely to accept Chinese traditions as they feel like the Other, as the unaccepted, the negatively judged against the dominant group, the Americans. Winnie's daughter tries effortlessly to negate her Chinese origins. She wants to be one of the crowd, to be American, to be Americans' equal, marrying an American guy, avoiding communication with her Chinese mother who was a strict Chinese, living far away from her mother. Ironically, as she strives to become American, she becomes Chinese.

Only when the two of them get to know each other so well as to predict the reactions of the other, the mutual understanding will arise. Winnie tries to share with her daughter the symbols, cultural patterns, her experiences so that her daughter can have a perception of what life in China is like. It is the cultural baggage that comes with her in America and it does not get lost, on the contrary, the Chinese symbols remain and Winnie lives the Chinese life at maximum intensity. To be able to address such a painful subject as the personality of Pearl's biological father, she has to present and explain her aims, aspirations, feelings and intentions to her daughter. Both are aware of the incompatibility of the two worlds, the old and the new, but also of the need for peaceful coexistence. Pearl's image of her mother Winnie has become stereotyped. Before their sincere conversation happens, the intercultural barriers between the two made us observe two sides that are clear and distinct. By accepting her mother's confession, the exchange of these distinct values is favored. Pearl's ethnocentrism loses ground in favor of knowing and accepting her Chinese origin.

The disclosure of Winnie's mother's home-beginning enigma begins with the inter-global confession in chapter Ten Thousand Things: "I never told you about my mother? That she left me? That's because I never wanted to believe it myself. So maybe that's why I did not tell you about her." (Tan 2013: 88)

This feature characterizes the entire Chinese Diaspora. It is a second-generation problem. "We can discover the others in ourselves, we can understand that we are not forming a homogenous and radically foreign substance of everything that is not self: I am another." (Todorov 1994: 45)

There is a point in the novel where each of the major Chinese-born American characters expresses anxiety over the inability to reconcile the Chinese heritage with the American surroundings. This is the very aim of Jing-mei's journey to China. The daughters are genetically Chinese and have been brought up in Chinese homes but they also identify themselves as American. Waverly, Rose and Lena have white boyfriends and husbands and they discourage their mothers' old-fashioned traditions. It can be said that they have been trying to escape the Chinese traditions. For instance, Lena would walk all day long with her eyes open to make them look American. Or, Lindo would clap her hands every time her mother told her she did not look Chinese.

\section{MOTHERS AND DAUGHTERS, PRIDE AND PREJUDICE}

These two opposing worlds, mothers and daughters, keep struggling to find their identities. Even if the daughters obey their mothers, they are more comfortable in the 
American world. It is too tempting for them not to enjoy this glittering "banned world" which, in fact welcomes them. A symbolic scene happens at the hair salon before the wedding when Lindo Jong goes accompanied by Waverly. One represents the new, the other the old. The mother wants to keep her haircut the same, she even threatens not to go to the wedding. In this way, she teaches the power of invisible strength to her Chinese American-born daughter and Waverly succeeds in being the best in chess due to her ability to hide her thoughts and to channel her powers. Waverly is a model of success, now an attorney. But she feels that she cannot rise to her mother's expectations when they talk about her white husband-to-be.

Her fear comes from the fact that it was her mother's critical point of view that made her see her first husband Marvin with unpleasant eyes. She is constantly waiting to lose Rich for the same reason. Her love for her daughter Shoshana teaches her unconditional love. Secondary to their competitive mothers, Jing-mei lives with the fear that her daughter might be wooed by the opportunities of the American world, which may endanger her curiosity for the Chinese world. Lindo herself sees herself as too "assimilated". Talking becomes a tool and eventually they strike a deal.

\section{THE ALTERITY BETWEEN THE CHINESE AND AMERICAN WORLDS, A PROBLEM OF ACCEPTANCE AND NON-ACCEPTANCE}

The two extremely different worlds are deepened by different situations concerning women. Repressed women in China have to bear as many children with a smile on their face never complaining and always obeying, standing in the shade of a man. On the contrary, free American women are advised to have careers and children only if they want to, they are encouraged to become independent. Having had a tragic life as the Chinese wives, the Chinese mothers know that their daughters can be truly happy only if they are brought up in a free country where women are encouraged to lead their own life, such as America.

Coming from these two opposing worlds, the daughters come to good terms with their mothers just later. The daughters want to have support from their mothers and to be encouraged, they want their mothers to be kind to them. They feel that they are not accepted in the American society, they feel rejected, they feel like outsiders and they like to find comfort in their mothers. But, instead, they get mothers who want them to be respectful and ready to be taught about the Chinese world that they value so much.

This gap reflects once again the great difference between the two opposing, contrasting worlds, the world of Acceptance and the world of Not Being Accepted. Only later, when daughters reach maturity, they start to see the world with different eyes, the same as Tan did after her mother recovered and took her to an initiation journey to China, which will be first in a row of many other trips. It is not until the daughters reach full maturity that they can understand the pressure that mothers had put on them.

Chinese mothers are strong and willful. They are described as stubborn in their aim to create happiness and success. They do not focus on their hardships. This is why they nurture their children and fiercely love their daughters, often expressed with criticism 
which comes from the fact that their daughters want to shake off their Chinese identity in favor of an American one. They belong to two different worlds, from two divergent cultures, two different cultural upbringings. There is one person who can switch from Chinese to American. And that person is Lindo from the novel The Joy Luck Club. But she cannot be at the same time both Chinese and American. As her daughter Waverly puts it, the two identities in this two-facedness succeed each other. The feeling of otherness is so acute that the fight between the two women, mother and daughter, becomes a tournament.

In the American version of The Joy Luck Club, Jing-mei who is 36 years old, is about to replace her mother at the table of a weekly game of mahjong as her mother died two months ago. Jing-mei, learns from aunt Lin of her mother's desire to find her two daughters abandoned in the drama of the exodus in China. Aunt Lin's English is poor, so the narration is in Chinese. The abandoned children had been discovered just before Jing-mei's mother died. It seems they were adopted. Before her death, Jing-mei's mother Suyuan managed to get the address of these two Chinese girls. She wrote them there and received a reply in Chinese. In another envelope, with the name of June Wu on it, Jing-mei is surprised to find that her mother left a 1,000 dollar check for her to travel to Shanghai to see her half-sisters, to announce her mother's death and to tell them about her mother's life. What to tell them about?, wonders Jing-mei and the other lucky women at the mahjong table are frightened because they realize that their daughters and granddaughters born in America are as careless as jing-mei about all the valuable truths and hopes their mothers brought with them to America.

Jing-mei Wu, looking through aunt's eyes, lives in her nostalgia for her Chinese origin, which can be seen in her persuasive words:

You MUST see your sisters and tell them about your mother's death...But the most important is to tell them about her life. The mother they did not know, they must know. [...] Tell them stories she told you, lessons she taught, what you know about her mind that has become your mind. Your mother was very smart lady. Tell about her kindness, her smartness, her dutiful nature to family, her hopes, things that matter to her. The excellent dishes she cooked. (Tan 1989: 34-35)

Jing-mei has always forced herself to be herself and to protest against rigid maternal education: when she did not get 10 on the line, when she did not become the boss of the class, when she did not go to Stanford, when she quit college.

It was not the only disappointment my mother felt in me. In the years that followed, I failed her so many times, each time asserting my own will, my right to fall short of expectation. I didn't get straight. As I didn't become class president. I didn't get to Stanford. I dropped out college. FOR UNLIKE MY MOTHER, I did not believe I could be anything I wanted to be. I COULD ONLY BE ME. (Tan 1989: 63)

We could not find more eloquent examples of alterity, or otherness of identity. 


\section{CHINESE ETHNIC ORGANIZATIONS HAVE ECHOES OF ANCESTRY}

Their framework includes suburban Chinese schools, associations, racial civil rights organizations. The Chinese immigrants are usually very tolerant and they know little about their rights as tenants. They do not want any trouble, they do not want to have anything to do with a lawsuit. If they did, it would mean they were not serious persons. Most of them live in Chinatowns or suburbs, others are ruled by well-educated Chinese who are accepted and assimilated by the American population.

All the features mentioned above are paradoxically coming from the Chinese immigrants' need to adapt. It seems that becoming an American becomes possible by maintaining Chinese ethnicity. It is a way of reaching the secular goal of becoming Chinese American. How? By enhancing the Chinese foundation in the right way. They ran away from China because they thought the country was sick, but once they reach the promised land, do they really want to leave everything behind? If yes, they have to confront China and everything Chinese in them first.

One of the most important problems when bringing immigration to the first page is that of community inhibition. Immigrants are socially isolated. It comes from group exclusivity. This rejection leads to stereotyping and racial discrimination. Native-born Asian Americans are often put in situations in which they have to show loyalty and patriotism as they are stereotyped. Chinatown is a stereotype. It has always been a term used to geographically distinguish the place in which Chinese immigrants cluster. There have been many other geographical borders to distinguish between different communities, like Little Italy, but Chinatown has survived for more than a century and yet has become a brand. It is a full-fledged immigrant community with a solid organizational structure with its economy. Based on sociological research, it gives credibility. Asians are depicted as a part of a success story of ethnic incorporation into American society. The second or later generation phenomenon appears too. However, they are more likely to gather around and keep their tradition intact.

Stereotypes are simplistic images, evenly fixed on a group or on a person or social process. They express anxious images, fears about the realization of things or phenomena, expectations from social situations or other groups of individuals. Everything is done according to some clichés. Walter Lippmann, the creator of this notion asserts that "we are determined to function on the basis of some images previously fixed in our mind, of abusive generalizations, of some memory sweeps." (Bourhis and Leyens 2009: 115-116)

The notion of stereotype evokes bias and discrimination. It leads to the idea of generalization and error of judgment, with unwanted consequences. The danger comes from the fact that stereotypes are labeling us. Stereotypes are closely related to the concept of collective mentality. This is an ensemble of perceiving, judging, acting, typical of the age, of a group, in our case of the study of the Chinese people in the twentieth century. It refers to the set of intellectual habits, opinions, beliefs, manners of behavior characteristic for a particular group. Generally, people who share the same belief have the same biases, the same convictions. This circuit is made through a kind of mental contagion by imitating the groups to which people relate. In Amy Tan's writing, we are dealing with affective relationships caused by different mentalities. With Amy 
Tan, beliefs are the result of affection and not of logic because their manifestation space is an affective circle (a family, a group of believers.) Faith is biased by prejudices, personal opinions, and it is created at the subconscious level. It is to be obeyed, not discussed. Winnie's tortures and her monologues in The Kitchen God's Wife and the mothers' confessions in The Joy Luck Club introduce us to the world of prejudices and opinions that revolve around the Chinese people, imprinting all the elements of ChineseAmerican civilization.

As for the faith in a certain dogma, it can be considered an illusion. In the Chinese doctrine, the unreal becomes stronger than the real. Much of Chinese beliefs and myths have a psychological charge that generates prejudices and opinions which are often despised by other peoples or ethnicities. Societies are generally characterized by two key elements:

i. the challenges of the natural environment and the social environment, and

ii. the ability to adapt to these challenges.

Thus, to call somebody Chinese means claiming cultural capital. But what is Chineseness? The issue of dis/claiming Chineseness starts from authenticity and hybridity. Family ties have always played a significant role in shaping the settlement patterns of Chinese immigrant waves. More than 80 percent of Chinese immigrants to the United States were sponsored by family members. The gateway cities are San Francisco, Los Angeles, and New York. The growing ethnic housing market offers Chinese immigrants the possibility to rent and buy. Their poor knowledge of English prevented them from satisfying their housing needs outside the ethnic market: buying, selling, rental services are time-consuming if one cannot speak the language. Subway is their only means of transport. They want a safe neighborhood with the right mix of ethnic groups: Chinese families, some Asians, and some Hispanics. That's why they have often been compared to a herd. When the first Chinese comes to one particular neighborhood, one must be sure that others will follow them. Chinatown is an important point of orientation for the Chinese, it is like an anchor. Though the Chinese pay a price for this exclusiveness: wages are low, extended families live for long periods in crowded areas, housing prices are high.

Families are pillars of the ethnic community. Family ties are based on common surname, ancestral descent, and the village of origin. There is also the district associations phenomenon which is based on the same dialect and last but not least, the merchant associations which are created according to the job they have. Religion also has a very important place within the Chinese society. They can be Protestants, Catholics, Buddhists, or Taoists.

Anyway, traditional Chinatowns show no sign of decline, but have actually grown and expanded. What has the Chinese population brought to the United States is diversity both for immigrants and the native population. Luminita Mihaela Iacob speaks of a dynamics of the criteria, arguing that the alterity between the master and the slave was overcome by the alterity of Christianity vs. the pagan. The latter alterity is overcome by the alterity between us vs. foreigners. Lack of information about the other has led to prejudices and stereotypes. In the case of collectives, we can witness the phenomenon of cultural shock. It is also the case of Amy Tan's Chinese characters who leave China for the American Dream - they would like to live in the United States. The rules followed in 
the two different worlds are also different. Faced with the different languages, different social habits and attitudes, the immigrants realize how separate the worlds can be. The immigrants are often bullied. The feeling of negativity comes to light. The diffused image that the two different worlds have about each other is also created due to their distance. For Pearl it is very hard to understand the Chinese world, although she is a true Chinese. Similarly, for her mother, Winnie, it is difficult to accept the American world.

In The Joy Luck Club, the condition of the other is presented from the perspective of self-assimilation to the American way of living after leaving China in 1949, when America was seen as the Promised Land. Suyuan had left home without regret, left her parents' house, her first husband and her two twin daughters:

My mother believed you could be anything you wanted to be in America. You could open a restaurant. You could work for the government and get good retirement. You could buy a house with almost no money down. You could become rich. You could become instantly famous. (Tan 1989: 151)

Suyuan chooses a different way of life for Jing-mei, her daughter born in America. She wants her to become famous and tells her examples of children who have become famous at her age, such as the actress Shirley Temple, or the chess player Waverly Yong in the Rules of the Game, the youngest chess champion of Chinatown. Once in the Promised Land, Suyuan takes her daughter to do an intelligence test. The daughter becomes bored of her mother's attempts to make a celebrity of her. Every night after dinner the two would sit at the Formica kitchen table. New tests would occur as well as the stories of exceptional children described in Ripley's Believe It or Not or Good Housekeeping, Reader's Digest.

She took the magazines from the houses she cleaned. She was looking for remarkable children. A nineteen-year-old Chinese girl playing the piano on TV screen would excite her mother who suddenly wants her girl to become a pianist. She finds a piano teacher on the same block where they live and agrees to do his housekeeping in exchange for weekly piano lessons for her daughter. Mother's approach does not coincide with that of Jing-mei who refuses it with a question: "Why don't you like me the way I am? I'm NOT a genius." (Tan 1989: 48)

\section{CONCLUSION}

Faith in general is defined as affective, sentimental, non-rational certainty that can sometimes attain fanaticism. Immanuel Kant (2003: 10) confirms that faith is an act of individual will, subjective adhesion, which excludes doubt and lacks adequate logical reasoning. Gustave Le Bon (1995: 9) launches the idea that a belief constrains us to admit an idea, an opinion.

Faith is the essential element of mentality. It is the source of social prejudices, it is the nucleus around which the mentality of society is clinging, enhancing a mark in the collective mentality and in their way of life. Amy Tan's characters interpret events based on fixed elements well-known collectively. The moment when the main character of The 
Kitchen God's Wife breaks the scissors is raised to catastrophe because the unwritten Chinese rules cannot be challenged. Then, tragic events are only expected by Winnie with resignation.

Winnie is a weak woman, oppressed by pain, humiliation, disgust. The more she suffers, the stronger she becomes. Her suffering is so great that at one point she can no longer be overcome by greater suffering. Winnie assumes the total suffering in order to be able to triumph over it, so that eventually no suffering could break her. That is why the next chapter, Weak and Strong starts with her confession.

That was my life, everything always in between-without hope, yet without despair; without resistance, but without acceptance. So you see, weak and strong. (Tan 2013: 313)

This comes as an act of revenge. Within a world in which humanity is strictly related to man while the woman is just a satellite, an incidental detail, opposed to the essential, there is a switch when "the other", the woman becomes a fighter, a winner (as her American name Winnie demonstrates), she knows how to dust herself and start all over again. She finally gets a sense of peace. It is that feeling that all the suppressed have after they survive periods of torture, of being excluded, of being inferior, contested, oppressed, of being considered outsiders, or being judged against.

\section{REFERENCES}

Bourhis, Y. R. and P. Jaques-Leyens (eds.). 2009. Stereotypes, discrimination and Intergroup relationships. New York: Taylor and Francis Group.

Cheung, K. 2000. Conversations with Asian American Writers. Honolulu: University of Hawaii Press.

Dictionar de filosofie. 1978. Bucuresti: Editura Politica.

George, L. J. 1999. The Asian Pacific American Heritage: A Companion to Literature and the Arts. New York: Garland.

Huang, G. 2006. The Columbia Guide to Asian American Literature since 1945. New York: Columbia UP.

Kant, I. 2003. Religion within the Boundaries of Mere Reason and Other Writings. Cambridge: CUP.

Kim, E. H. 1982. Asian American Literature: An Introduction to the Writings and Their Social Context. Philadelphia: Temple UP.

Le Bon, G. 1995. Opiniile si credintele. Bucharest: Ed Stiintifica.

Tan, A. 1989. The Joy Luck Club. London: Random House.

Tan, A. 2003. The Opposite of Fate: A Book of Musings. New York: Putnam.

Tan, A. 2013. The Kitchen God's Wife. New York: HarperCollins Publishers.

Tzvetan T. 1994. Cucerirea Americii. Problemele celuilalt. Iași: Institutul European. 


\section{SUMMARY}

\section{MOTHERS AND DAUGHTERS IN AMY TAN'S THE KITCHEN GOD'S WIFE AND THE JOY LUCK CLUB}

The focus of this paper is the theme of "Otherness" in Amy Tan's novels The Kitchen God's Wife and The Joy Luck Club. The paper discusses the characteristics of "Otherness", proposing four specific peculiarities: the Sino-American female identity following the tale of Pearl, the In-group and the Out-group concept, the place of women within a patriarchal society, and the special heterogeneity of society. It approaches the theme of Otherness between the American born daughter, Pearl Louie Brandt, and the mother, Winnie Louie, a Native Chinese. The paper underlies the alterity between the In-group (the Native Americans), and the Out-group (the Chinese). Last but not least, the paper deals with the spatial heterogeneity of society, another very important characteristic of "Otherness".

KEYWORDS: The Kitchen God's Wife, The Joy Luck Club, Chinese women, tradition, identity, race, stereotypes, struggle.

ARTICLE INFO:

Original scientific paper

Received: April 1, 2020

Revised: December 16, 2020

Accepted: December 23, 2020 